\title{
Review on the Influence of Temperature upon Hydrogen Effects in Structural Alloys
}

\author{
Thorsten Michler*(D), Frank Schweizer and Ken Wackermann
}

Citation: Michler, T.; Schweizer, F.; Wackermann, K. Review on the Influence of Temperature upon Hydrogen Effects in Structural Alloys. Metals 2021, 11, 423. https:// doi.org/10.3390/met11030423

Academic Editor: Martin Heilmaier

Received: 3 February 2021

Accepted: 26 February 2021

Published: 4 March 2021

Publisher's Note: MDPI stays neutral with regard to jurisdictional claims in published maps and institutional affiliations.

Copyright: (C) 2021 by the authors Licensee MDPI, Basel, Switzerland. This article is an open access article distributed under the terms and conditions of the Creative Commons Attribution (CC BY) license (https:/ / creativecommons.org/licenses/by/ $4.0 /)$.
Fraunhofer Institute for Mechanics of Materials, Woehlerstrasse 11, 79108 Freiburg, Germany; frank.schweizer@iwm.fraunhofer.de (F.S.); ken.wackermann@iwm.fraunhofer.de (K.W.)

* Correspondence: thorsten.michler@iwm.fraunhofer.de

\begin{abstract}
It is well-documented experimentally that the influence of hydrogen on the mechanical properties of structural alloys like austenitic stainless steels, nickel superalloys, and carbon steels strongly depends on temperature. A typical curve plotting any hydrogen-affected mechanical property as a function of temperature gives a temperature $T_{H E \text {, max }}$, where the degradation of this mechanical property reaches a maximum. Above and below this temperature, the degradation is less. Unfortunately, the underlying physico-mechanical mechanisms are not currently understood to the level of detail required to explain such temperature effects. Though this temperature effect is important to understand in the context of engineering applications, studies to explain or even predict the effect of temperature upon the mechanical properties of structural alloys could not be identified. The available experimental data are scattered significantly, and clear trends as a function of chemistry or microstructure are difficult to see. Reported values for $T_{H E \text {, max }}$ are in the range of about 200-340 K, which covers the typical temperature range for the design of structural components of about $230-310 \mathrm{~K}$ (from -40 to $+40{ }^{\circ} \mathrm{C}$ ). That is, the value of $T_{H E, \max }$ itself, as well as the slope of the gradient, might affect the materials selection for a dedicated application. Given the current lack of scientific understanding, a statistical approach appears to be a suitable way to account for the temperature effect in engineering applications. This study reviews the effect of temperature upon hydrogen effects in structural alloys and proposes recommendations for test temperatures for gaseous hydrogen applications.
\end{abstract}

Keywords: hydrogen embrittlement; temperature effect; steel; nickel-based superalloys

\section{Introduction}

The European Commission (and other major industrial regions) developed road maps and implementation plans to reduce greenhouse gas emissions, and hydrogen plays a predominant role in this strategic vision [1]. It has been known for over one century that hydrogen deteriorates the mechanical properties of most structural metallic alloys, especially steels [2], also known as "hydrogen embrittlement." For a safe and affordable hydrogen economy, this phenomenon must be considered in the design process. Several national and international standards like EN 1594-2020, SAE J2579, EIGA 100/03/E, and ASME B31.12 address the important topic of a proper materials selection for hydrogenwetted components, in particular those components which contain a high inner hydrogen gas pressure.

It is well-documented experimentally that the influence of hydrogen on the mechanical properties of various structural alloys like austenitic stainless steels (e.g., [3]), nickel superalloys (e.g., [4]), and carbon steels (e.g., [5]) strongly depends on temperature. A typical curve plotting any hydrogen-affected mechanical property as a function of temperature gives a temperature $T_{H E, \max }$, where the degradation of this mechanical property reaches a maximum. Above and below this temperature, the degradation is less. An example is shown in Figure 1, where the tensile relative reduction of area of 316 austenitic stainless 
steel is plotted as a function of temperature [3]. Here, the remaining tensile ductility reached a minimum, i.e., the degradation reaches a maximum at temperatures around $220 \mathrm{~K}$. A precise explanation for this phenomenon is very complex [6]. In [6], the temperature effect was reviewed and discussed in the context of the relevant hydrogen-metal interactions along the so called "hydrogen reaction chain," i.e., (i) the transport of hydrogen to the crack tip, (ii) physical adsorption, (iii) dissociative chemical adsorption, (iv) hydrogen absorption, (v) the transport of hydrogen to regions of tensile stress, and (vi) hydrogen material interactions, all of which are temperature-dependent. It was concluded that slow hydrogen transport limits hydrogen effects at low temperatures whereas negligible hydrogen trapping especially at dislocations limits hydrogen effects at high temperatures. Intermediate temperatures allow for hydrogen-dislocation interactions with a maximum interaction at $T_{H E \text {,max }}$, which is alloy-dependent. Unfortunately, a sophisticated quantification of such mechanisms was not provided. However, this concept was used as a starting point in the discussion section. For various structural alloys, $T_{H E, \max }$ values in the range of about $200-340 \mathrm{~K}$ are frequently reported using tensile tests, e.g., [3,5,7]. It appears that $T_{H E, \max }$ is strongly material-dependent, and the gradient additionally depends on environmental parameters (e.g., hydrogen pressure [3,8]) and loading parameters [3,9]. A typical temperature range for the design of structural components is about $230-310 \mathrm{~K}$ (from -40 to $+40{ }^{\circ} \mathrm{C}$ ), which lies well within the above-mentioned range of $T_{H E \text {, max }}$. That is, the value of $T_{H E, \max }$ itself, as well as the slope of the gradient, might affect the material selection for a dedicated application. The goal of this study was to review the effect of temperature on the hydrogen effects of structural alloys and to propose recommendations for test temperatures for gaseous hydrogen applications.

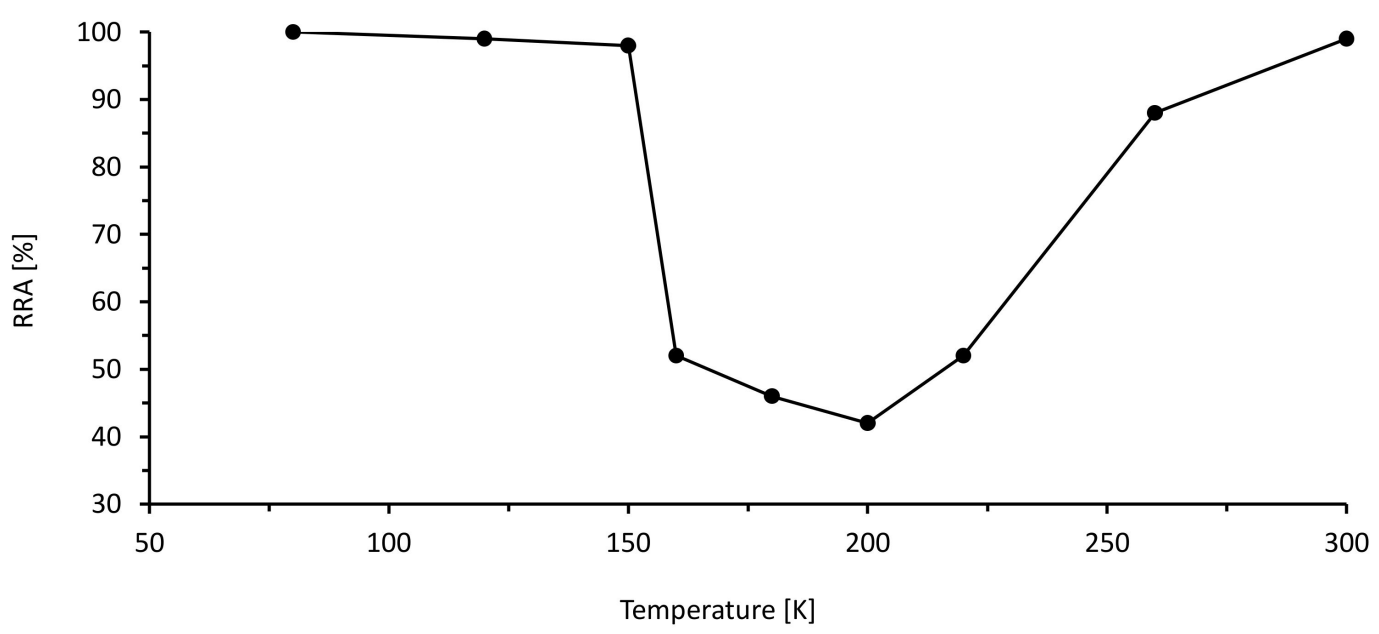

Figure 1. Relative reduction of area $\left(\mathrm{H}_{2} / \mathrm{He}\right)$ in tensile tests as a function of test temperature for 316 stainless steel with a hydrogen test pressure of $1 \mathrm{MPa}$, adapted from [3]. $\mathrm{RRA}=\mathrm{RA}_{\mathrm{H} 2} / \mathrm{RA}_{\text {ref }}$ in $\%$. RA: tensile reduction of area; RRA: relative reduction of area.

\section{Data Analysis}

A typical graph plotting any Hydrogen Effects Index (HEI) on the mechanical properties of structural alloys as a function of temperature is shown in Figure 1. Such graphs are characterized by (i) the temperature $T_{H E, \max }$, where the degradation of this mechanical property reaches a maximum, and by (ii) the gradient of the HEI. Though the gradient below and above $T_{H E, \max }$ must not be identical, it appears from Figure 1 that such trends might be reasonably well-described by a parabolic function.

In an HEI-T coordinate system, we find:

$$
H E I=A\left(T-T_{H E, \max }\right)^{2}+H E I_{\min }
$$


where factor $A$ characterizes the gradient of the HEI and can easily be calculated by inserting any second experimental data point into Equation (1).

This review focuses on the analysis of $T_{H E \text {, max }}$ of austenitic stainless steels, iron- and nickel-based superalloys, and carbon and low alloyed steels. Data from tests in hydrogen atmosphere, from tests with gaseous hydrogen-precharged specimens, and from tests with electrolytical hydrogen-precharged specimens were included in this review. All reviewed data are summarized in Tables 1-3. Typically, mechanical properties decrease under the influence of hydrogen, i.e., such HEI-T graphs show a minimum. This is true for tensile tests, fracture toughness tests, and fatigue-life tests. On the contrary, in cyclic crack growth tests, the degradation under the influence of hydrogen is characterized by an increase in crack growth rate, i.e., such HEI-T graphs show a maximum. In reviewing the experimental data, it could be seen that $T_{H E, \max }$ was defined as the temperature of the extreme value of the experimentally reported HEI (Figure $2 b$ ) and not the extreme value of any fitted curve. Since experiments were typically performed at defined temperature intervals $(\Delta T)$, a range of $\pm 0.5 \Delta \mathrm{T}$ was defined to characterize the error of $T_{H E, \max }$ (Figure $2 \mathrm{~b}$ ).

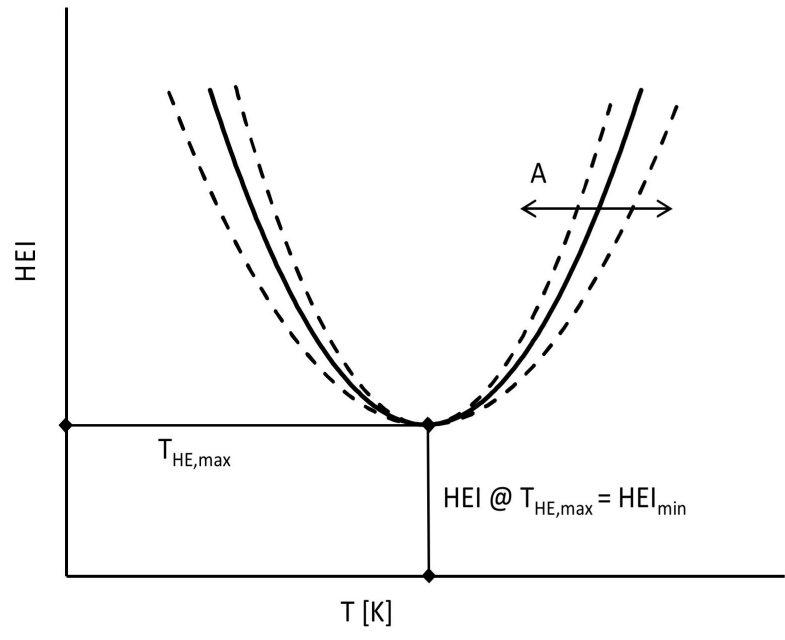

(a)

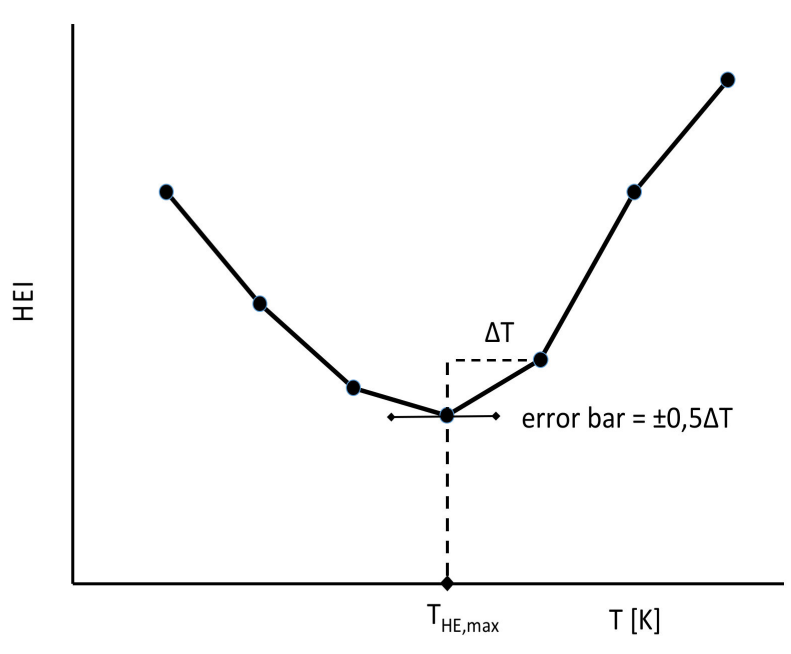

(b)

Figure 2. (a) General parabolic function and its characteristic parameters and (b) sketch illustrating the data acquisition of $T_{H E, \max }$.

\section{Results}

\subsection{Austenitic Stainless Steels}

The effect of temperature on the tensile ductility of 300 series stainless steels in the solution-treated condition was investigated in various studies $[3,7,8,10-21]$. Some studies reported the reduction of area (RA) measured under the influence of hydrogen [16-19], but most studies reported the relative reduction of area (RRA) as the ratio of RA measured under the influence of hydrogen and in a control atmosphere, e.g., air, $\mathrm{He}$, or $\mathrm{Ar}$ $\left(\mathrm{RRA}=\mathrm{RA}_{\mathrm{H} 2} / \mathrm{RA}_{\text {Control }}\right)$.

The tensile strain rate strongly influences hydrogen effects in most structural materials [22], and a tensile strain rate lower than $10^{-4} \mathrm{~s}^{-1}$ is recommended to capture full hydrogen effects. Figure 3a,b shows $T_{H E, \max }$ values of solution-treated 304- and 316-type austenitic stainless steels measured at tensile strain rates less than $10^{-4} \mathrm{~s}^{-1}$ for tests in hydrogen gas and gaseous hydrogen-precharged specimens. Results were very consistent around $200-220 \mathrm{~K}$ and appeared to be independent on the hydrogen charging method, i.e., tests in hydrogen gas $[3,8,11-15,19-21]$ compared to tests with hydrogen-precharged specimens [7,16-19]. Additionally, alloying up to $10 \mathrm{wt} \% \mathrm{Mn}$ in 316 grades appeared to have a negligible influence on $T_{H E, \max }$ [13]. Analyzing $T_{H E, \max }$ as functions of tensile strain rate [3,7,11,16-19] (Figure 3c) demonstrated that the hydrogen gas pressure for 
tests performed in hydrogen gas $[3,8,11-15,21,22]$ (Figure 3d) and the hydrogen content for tests performed with gaseous [7,10,16-18] or electrolytic [19] precharged specimens (Figure 3e) showed no significant influence of either parameter within the given parameter ranges. $T_{H E, \max }$ of $\mathrm{CrMnN}$ austenitic stainless steels was reported to be around $250 \mathrm{~K}$ (Figure 3f) [7,18], which is higher than that of 304- and 316-type austenitic stainless steels. The $T_{H E, \max }$ data of the sensitized 304 and 316 grades fell within the range of solutionannealed grades, whereas the value for a cold-worked 316 grade was reported to be about $150 \mathrm{~K}$ (Figure 3g) $[3,13,14]$. This review shows that measuring the influence of temperature upon hydrogen effects in austenitic stainless steels using tensile tests gives quite consistent results, being robust against many test variables. The analysis of 47 datasets revealed a $T_{H E, \max }$ value of $204 \pm 20 \mathrm{~K}$ (mean and standard deviation) for 304- and 316-type austenitic stainless steels (excluding CrMnN austenitic stainless steels).

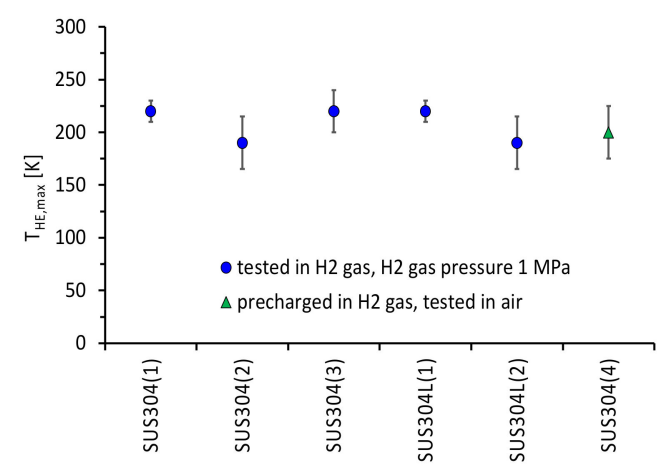

(a)

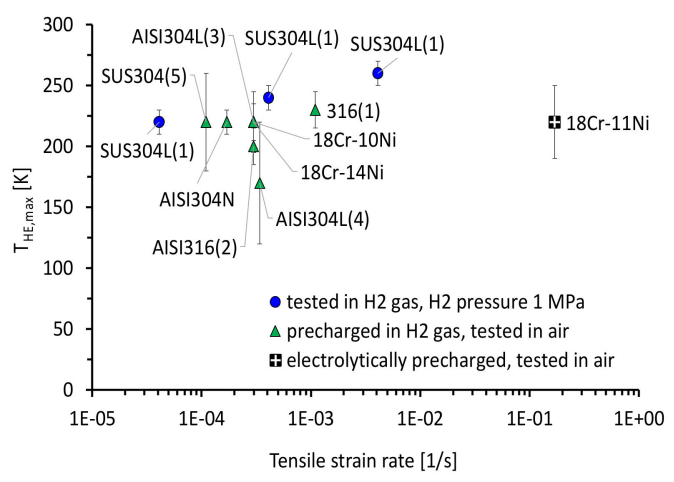

(c)

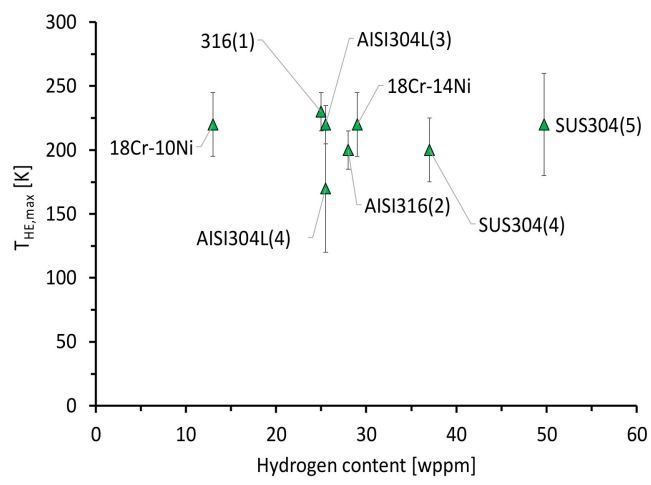

(e)

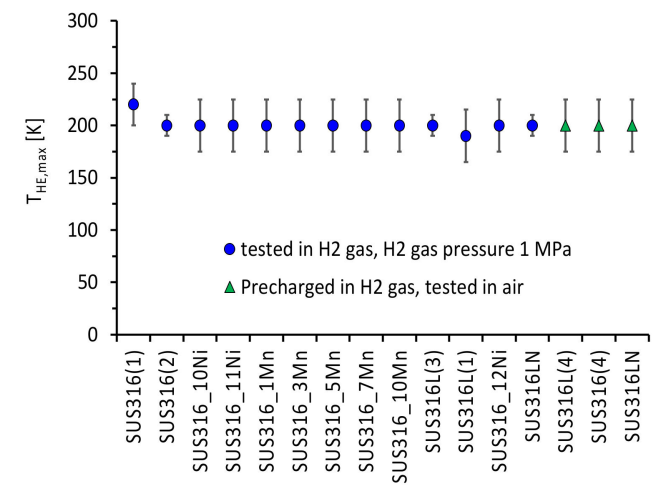

(b)

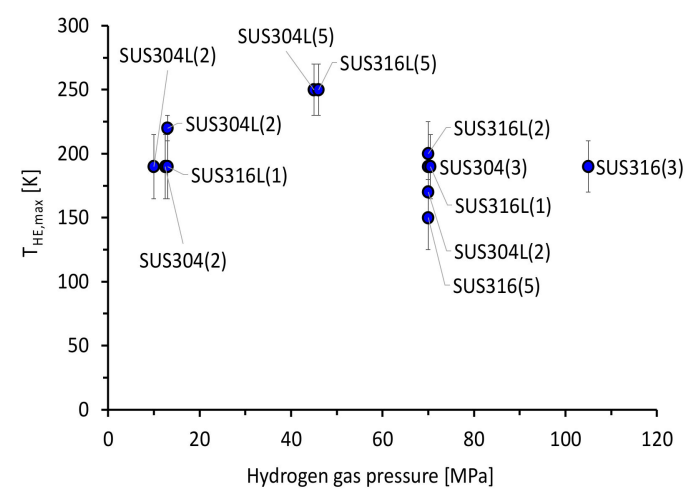

(d)

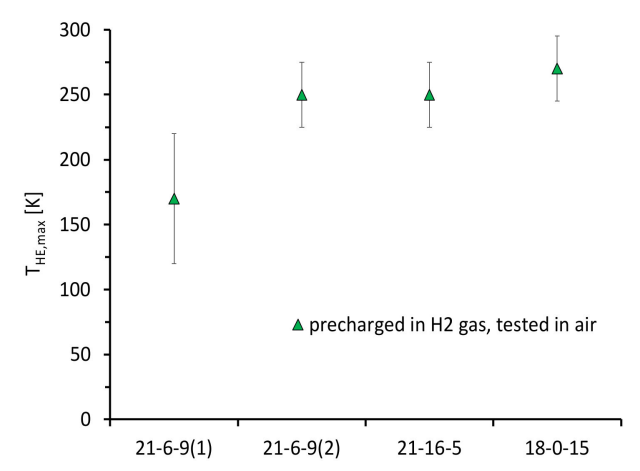

(f)

Figure 3. Cont. 


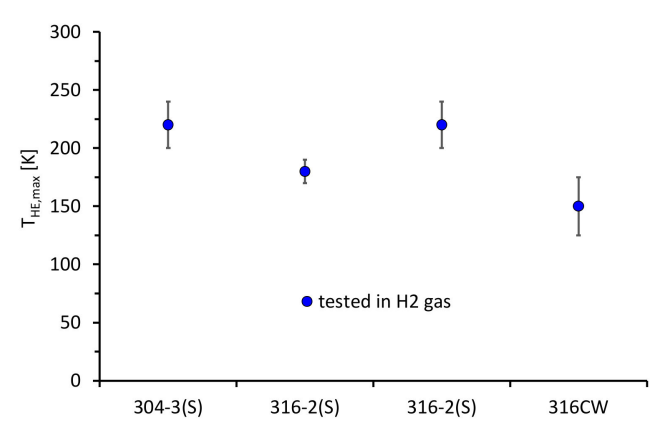

$(\mathrm{g})$

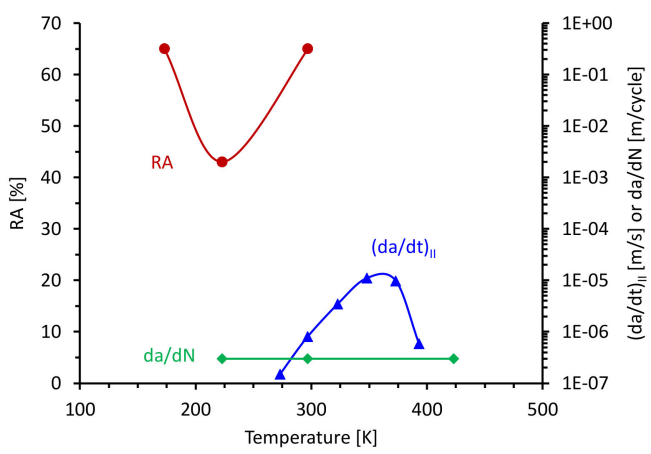

(h)

Figure 3. $T_{H E \text {, } \max }$ of austenitic stainless steels, (a) solution-treated 304-type steels with tensile strain rate of $<10^{-4} \mathrm{~s}^{-1}$; (b) solution-treated 316-type steels with a tensile strain rate of $<10^{-4} \mathrm{~s}^{-1}$; (c) solution-treated 304- and 316-type steels as a function of tensile strain rate; (d) solution-treated 304- and 316-type steels, tested in hydrogen gas, as a function of hydrogen gas pressure; (e) solution-treated and hydrogen-precharged 304- and 316-type steels as a function of $\mathrm{H}$ content; (f) solution-treated CrMnN steels—-the numbers indicate the nominal alloying contents of Cr-Ni-Mn; (g) sensitized (S) and cold-worked (CW) 304- and 316-type austenitic stainless steels; and (h) reduction of area (RA) in tensile tests [19], stage II crack growth rate $\left((\mathrm{da} / \mathrm{dt})_{\mathrm{II}}\right)$ [9], and cyclic crack growth rate $\left(\mathrm{da} / \mathrm{dN}\right.$ at $\left.\Delta \mathrm{K}=30 \mathrm{MPa} \mathrm{m}^{0.5}\right)$ [23] as a function of temperature. The references for all data points are given in Table 1.

Another variable influencing $T_{H E, \max }$ might be the loading condition represented by the test method. A significantly higher $T_{H E, \max }$ value of $360 \mathrm{~K}$ was reported for 301 austenitic stainless steel when using sustained crack growth tests [9], which is about $150 \mathrm{~K}$ higher than what is consistently reported for tensile RA results (Figure 3h). A negligible influence of temperature on cyclic da/ $\mathrm{dN}$ crack growth of a 1.4581 cast austenitic SS was reported in [23] (Figure 3h). Both were single datasets, and a verification of such results could not be found in the open literature. All results are summarized in Table 1.

\subsection{Nickel, Nickel-Based, and Iron-Based Superalloys}

Inconel 718 is a frequently tested alloy for hydrogen applications. Figure 4a shows $T_{H E, \max }$ values acquired by different test methods (tensile tests $[4,24,25]$, fracture toughness tests $\left(\mathrm{K}_{\mathrm{H}}\right)$ [4], and low cycle fatigue (LCF) tests [25]). A consistent $T_{H E \text {,max }}$ value around room temperature $(300 \mathrm{~K})$ was reported, independent of the test method. These results did not support the findings for austenitic stainless steels, where $T_{H E, \max }$ appears to depend on the test method (Figure $3 \mathrm{~h}$ ). Figure $4 \mathrm{~b}$ summarizes the $T_{H E \text {,max }}$ values of various other iron-based and nickel-based superalloys with values around room temperature $(270-300 \mathrm{~K})[4,7,18,19,26,27]$. When comparing solution-treated microstructures like in AISI 310 with age-hardened microstructures like in Inconel 718, it can be speculated that the effect of precipitations on $T_{H E, \max }$ is marginal within the group of materials analyzed here. On the other hand, the $T_{H E \text {, } \max }$ values of pure nickel were reported to be as low as $220 \mathrm{~K}[28,29]$. An analysis of 14 datasets revealed a $T_{H E, \max }$ value of $295 \pm 36 \mathrm{~K}$ (mean and standard deviation) for iron-based and nickel-based superalloys (excluding pure nickel). It should be noted here that the high standard deviation of $\pm 36 \mathrm{~K}$ is mainly caused by the high $T_{H E, \max }$ value of the cobalt-containing alloy Udimet 700 (Figure $4 \mathrm{~b}$ ). Excluding Udimet 700 from the statistics would result in a mean $T_{H E, \max }$ value of $286 \pm 25 \mathrm{~K}$. All results are summarized in Table 2. 


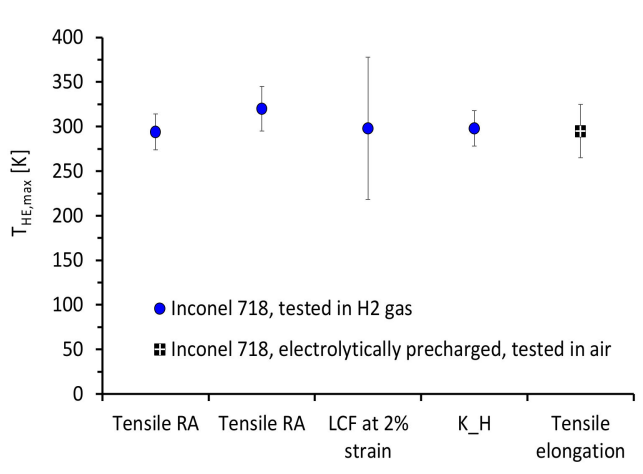

(a)

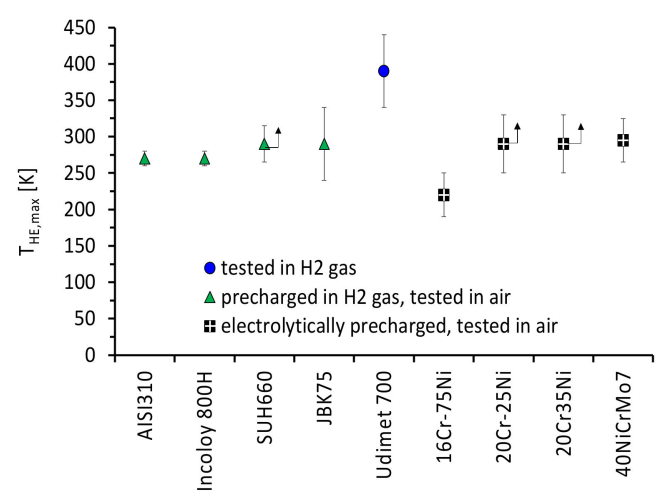

(b)

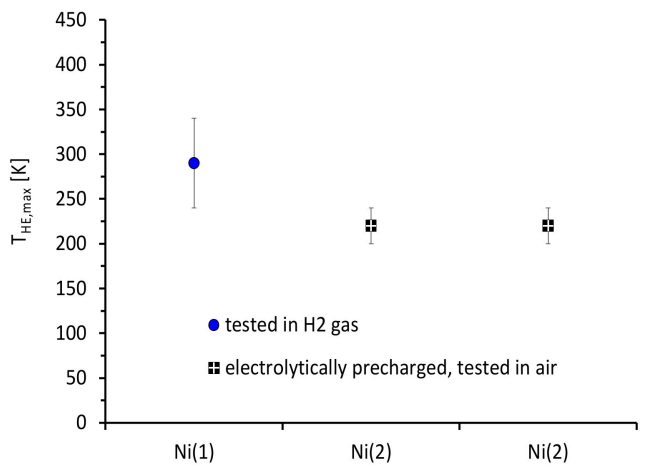

(c)

Figure 4. $T_{H E, \max }$ of nickel, nickel-based, and iron-based superalloys: (a) Inconel 718 tested using various test methods, (b) various iron- and nickel-based superalloys (an arrow indicates the temperature where maximum hydrogen effects were reported; $T_{H E, \max }$ can be higher than indicated), and (c) pure nickel. The references for all data points are given in Table 2.

\subsection{Steels with a Cubic Body-Centered (bcc) Lattice}

Multiple results were found in the open literature while investigating the effect of temperature upon the mechanical properties of steels with a bcc microstructure (ferrite, pearlite, bainite, martensite, etc., and combinations thereof); see Table 3. To simplify the presentation, the data were grouped into four steel classes, i.e., iron [30,31], carbon steels [5,30,32-35], heat-treatable steels [13,32,36-44], and high alloyed bcc steels [9,13,45-50]. The $T_{H E, \max }$ data for bcc steels scattered significantly. However, for tensile tests performed in gaseous hydrogen atmosphere, $T_{H E \text {,max }}$ appears not to be dependent on tensile strain rate (Figure 5a) or on hydrogen gas pressure (Figure $5 b$ ). Any trend within the selected steel classes could also not be identified. This confirmed the findings from austenitic stainless steels (Figure $3 c, d$ ). In addition, $T_{H E, \max }$ appears to be independent of the test method used to investigate the temperature effect, as can be seen in Figure $5 a-d$. In Figure $5 c, d$, all reported data for bcc steels are plotted as a function of the tensile strength of the tested steels. Again, no clear trend could be observed. The analysis of 46 datasets including, all four steel classes mentioned above, revealed a $T_{H E \text {, max }}$ value of $260 \pm 42 \mathrm{~K}$ (mean and standard deviation). 


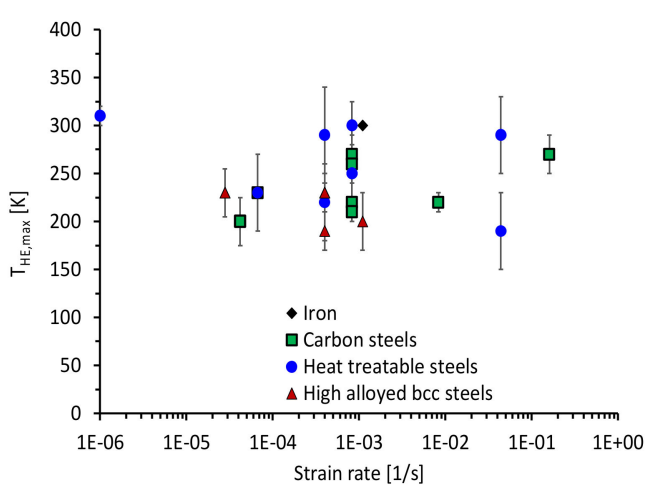

(a)

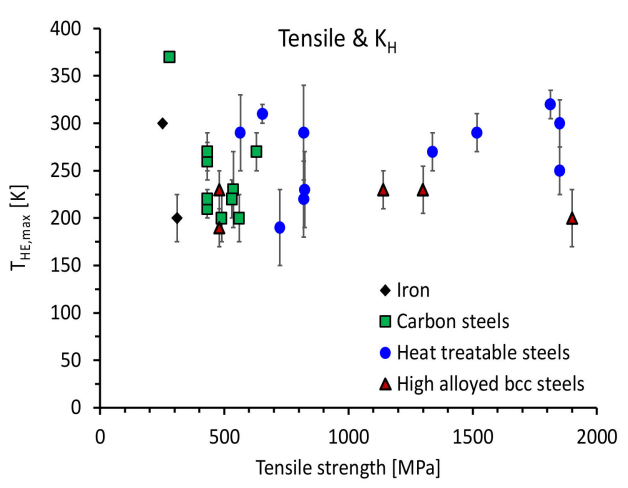

(c)

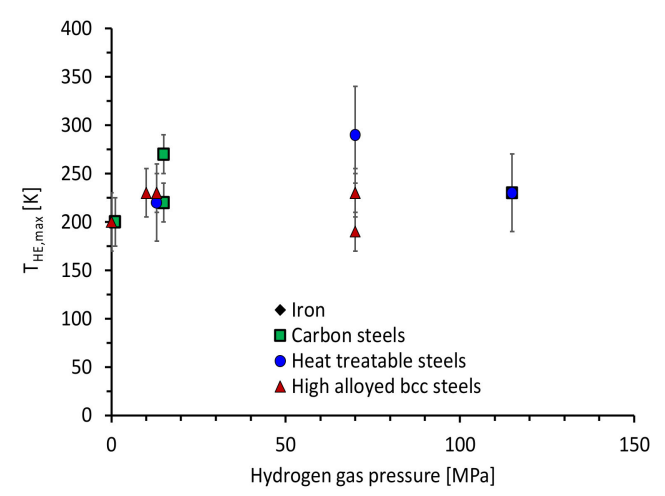

(b)

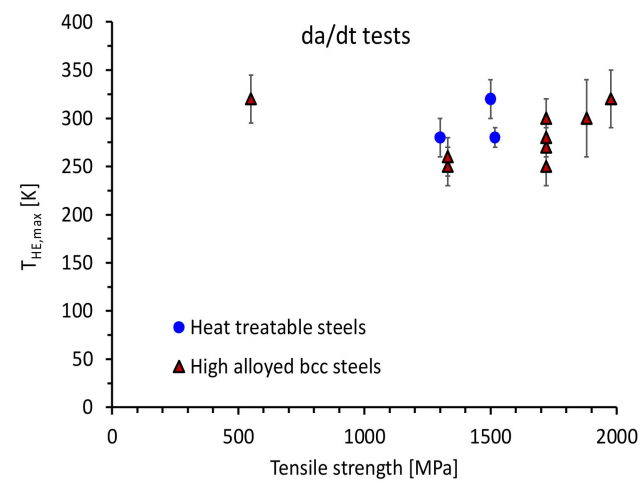

(d)

Figure 5. $T_{H E, \max }$ of bcc steels (a) as a function of tensile strain rate for tests performed in gaseous hydrogen atmosphere, (b) as a function of hydrogen gas pressure for tests performed in gaseous hydrogen atmosphere, and (c,d) as a function of tensile strength. The references for all data points are given in Table 3.

\section{Discussion}

About 50 references were identified in the literature that contained experimental studies on the influence of temperature upon hydrogen effects in structural alloys. Unfortunately, only a very few studies were found to offer a sophisticated interpretation. One reason might be the very complex nature of hydrogen effects in structural alloys, which makes temperature effects even harder to interpret [6]. It was found that pure metals like $\mathrm{Fe}, \mathrm{Ni}$, Ti, and $\mathrm{V}$ show more than one ductility minimum as a function of temperature [31]. That is, structural alloys might show more than one ductility minimum, but no experimental data could be identified in the open literature.

The first part of the discussion focuses on material science aspects in the context of the rate-limiting steps in the hydrogen reaction chain (Figure 6), which are (i) the transport of hydrogen to the crack tip, (ii) physical adsorption, (iii) dissociative chemical adsorption, (iv) hydrogen absorption, (v) the transport of hydrogen to regions of tensile stress, and (vi) hydrogen material interactions [6]. All of the above-mentioned steps are temperaturedependent [6]. A curve with an extreme value, as shown in Figure 1, is typically found in the case of at least two competing rate-limiting steps.

A model proposed in [36-39] based on the coverage of hydrogen adsorption sites was proven to contain misinterpretations [51], but this basic assumption was used as a starting point for improved models. A semi quantitative model explaining the influence of temperature on hydrogen effects based on trap coverage at the crack tip was able to qualitatively explain the ductility minimum in gaseous hydrogen experiments [52]. However, ductility minima were found in experiments performed in a gaseous hydrogen atmosphere, as well as with hydrogen-precharged specimens (Tables 1-3). That is, it appears very unlikely that steps 1-4 (the transport of hydrogen to the crack tip, physical adsorption, dissociative 
chemical adsorption, and hydrogen absorption) are the primary rate-controlling steps because such four steps are only relevant for tests in a gaseous hydrogen atmosphere.

Hydrogen transport over distances larger than a few grain diameters is controlled by bulk Fickian diffusion characterized by diffusivity (D). The diffusivities at room temperature are in the order of $10^{-15}-10^{-16} \mathrm{~m}^{2} / \mathrm{s}$ for austenitic stainless steels [53] and nickel-based superalloys like Inconel 718 [54], and they are $10^{-8}-10^{-11} \mathrm{~m}^{2} / \mathrm{s}$ for bcc steels depending on the microstructure $[55,56]$. The diffusivities of austenitic stainless steels and nickelbased superalloys are similar, but the $T_{H E, \max }$ values differ significantly (Figure 6). On the contrary, the diffusivities of bcc steels, austenitic steels, and nickel-based superalloys differ by several orders of magnitude, but their $T_{H E, \max }$ values greatly overlap (Figure 6). If bulk hydrogen transport was a primary rate-controlling step (at temperatures around room temperature), the $T_{H E, \max }$ values of bcc steels, on the one hand, and austenitic steels and nickel-based superalloys, on the other hand, would be clearly different, which is not the case.

If steps $1-5$ of the hydrogen reaction chain are not rate-limiting, then the temperaturedependent mechanisms involved in the hydrogen-material interactions (step 6) must control $T_{H E, \max }$. There is experimental evidence that hydrogen influences dislocation motion. In this case, the temperature-dependent interaction of hydrogen with dislocations might play a predominant role controlling $T_{H E, \max }[6,57]$. Unfortunately, such mechanisms are not currently understood to the level of detail required to study temperature effects. However, modern simulation tools may provide the framework to study such effects since a model based on hydrogen accumulation and diffusion around a micro crack using embedded atom methods and density functional theory calculations showed promising results [42].

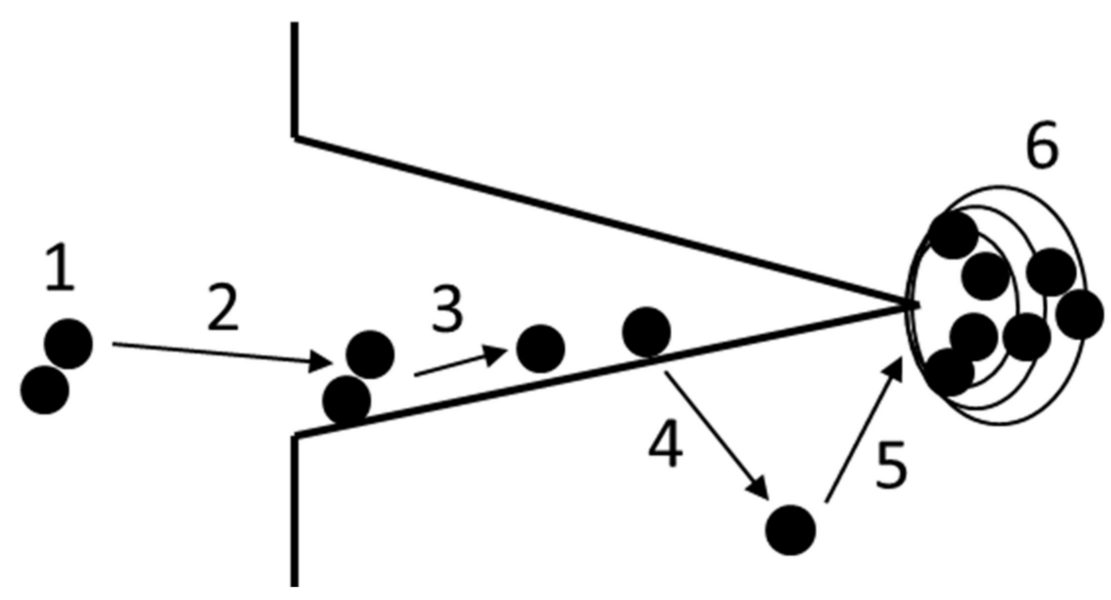

Figure 6. Rate-limiting steps for the transport of hydrogen to the fracture propagation zone, adapted from [58]. Here, 1 = transport of hydrogen to the crack tip; 2 = physical adsorption; $3=$ dissociative chemical adsorption; $4=$ hydrogen absorption; $5=$ transport of hydrogen to regions of tensile stress; and $6=$ hydrogen material interactions.

The second part of the discussion focuses on the statistical evaluation of the results for engineering applications. The histograms of the reviewed datasets for austenitic stainless steels (excluding CrMnN steels and cold-worked austenitic steels), iron-based and nickelbased superalloys (excluding pure nickel and Udimet 700), and bcc steels are shown in Figure 7a. The data for austenitic stainless steels and superalloys seemed to be represented by a normal distribution, whereas the data for bcc steels seemed not to be normally distributed. However, to compare the three material classes, a normal distribution was assumed for all three datasets. The corresponding Gaussian curves are given in Figure 7b. 


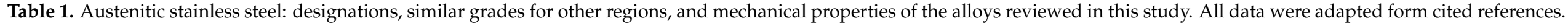

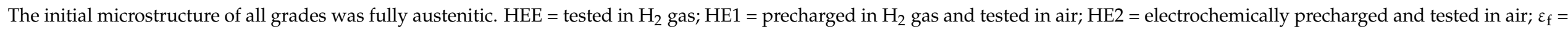
tensile elongation at fracture.

\begin{tabular}{|c|c|c|c|c|c|c|c|c|c|c|}
\hline \multirow[b]{2}{*}{ Reference } & \multicolumn{3}{|c|}{ Steel Designation } & \multirow{2}{*}{$\begin{array}{l}\text { Mechanical Property } \\
\text { Used to Assess HE } \\
\text { Effects }\end{array}$} & \multirow{2}{*}{$\begin{array}{c}\text { Strain Rate } \\
1 / \mathrm{s}\end{array}$} & \multirow[b]{2}{*}{$\begin{array}{l}\text { Hydrogen Charging } \\
\text { Method }\end{array}$} & \multirow{2}{*}{$\begin{array}{c}\text { H Content } \\
\text { wppm }\end{array}$} & \multirow{2}{*}{$\begin{array}{c}\text { H2 Test Pressure } \\
\text { MPa }\end{array}$} & \multirow{2}{*}{$\frac{T_{H E, \max }}{\mathbf{K}}$} & \multirow{2}{*}{$\begin{array}{l}\Delta \mathrm{T} \\
\mathrm{K}\end{array}$} \\
\hline & $\begin{array}{l}\text { As Given in } \\
\text { Reference }\end{array}$ & Used Here & $\begin{array}{l}\text { Equivalent } \\
\text { Grades }\end{array}$ & & & & & & & \\
\hline [11] & SUS304 & SUS304(1) & 1.4301, AISI 304 & tensile RRA & $4.1 \times 10^{-5}$ & HEE & - & 1.1 & 220 & 10 \\
\hline [13] & SUS304 & SUS304(2) & 1.4301, AISI 304 & tensile RRA & $2.8 \times 10^{-5}$ & HEE & - & 1 & 190 & 25 \\
\hline [14] & SUS304 & SUS304(3) & 1.4301, AISI 304 & tensile RRA & $4.2 \times 10^{-5}$ & HEE & - & 1 & 220 & 20 \\
\hline [11] & SUS304L & SUS304L(1) & 1.4306, AISI304L & tensile RRA & $4.1 \times 10^{-5}$ & HEE & - & 1.1 & 220 & 10 \\
\hline [27] & SUS304 & SUS304(4) & 1.4301, AISI 304 & tensile RRA & $4.2 \times 10^{-5}$ & HE1 & 37 & - & 200 & 25 \\
\hline [16] & 12Kh18N10T & $316(1)$ & 1.4401, AISI 316 & tensile RA & $1.1 \times 10^{-3}$ & HE1 & 25 & - & 230 & 15 \\
\hline$[7,59]$ & AISI316 & AISI316(2) & 1.4401, SUS 316 & tensile RRA & $3 \times 10^{-4}$ & HE1 & 28 & - & 200 & 15 \\
\hline$[7,59]$ & $18 \mathrm{Cr}-10 \mathrm{Ni}$ & $18 \mathrm{Cr}-10 \mathrm{Ni}$ & exp. heat & tensile RRA & $3 \times 10^{-4}$ & HE1 & 13 & - & 220 & 25 \\
\hline$[7,59]$ & $18 \mathrm{Cr}-14 \mathrm{Ni}$ & $18 \mathrm{Cr}-14 \mathrm{Ni}$ & exp. heat & tensile RRA & $3 \times 10^{-4}$ & HE1 & 29 & - & 220 & 25 \\
\hline$[7,59]$ & $304 \mathrm{~L}$ & AISI304L(3) & 1.4306, SUS 304L & tensile RRA & $3 \times 10^{-4}$ & HE1 & 25.5 & - & 220 & 15 \\
\hline$[7,59]$ & $304 \mathrm{~N}$ & AISI304N & 1.4301, AISI 304N1 & tensile RRA & $1.7 \times 10^{-4}$ & HE1 & - & - & 220 & 10 \\
\hline [17] & SUS304 & SUS304(5) & 1.4301, AISI 304 & tensile rel. $\varepsilon_{\mathrm{f}}$ & $1.1 \times 10^{-4}$ & HE1 & 49.7 & - & 220 & 40 \\
\hline [18] & $304 \mathrm{~L}$ & AISI304L(4) & 1.4306, SUS 304L & tensile RRA & $3.4 \times 10^{-4}$ & HE1 & 25.5 & - & 170 & 50 \\
\hline [19] & $18 \mathrm{Cr} 11 \mathrm{Ni}$ & $18 \mathrm{Cr}-11 \mathrm{Ni}$ & exp. heat & tensile RA & $1.7 \times 10^{-1}$ & HE2 & 15 & - & 220 & 30 \\
\hline [3] & SUS316 & SUS316(2) & 1.4401, AISI 316 & tensile RRA & $4.2 \times 10^{-5}$ & HEE & - & 1.1 & 200 & 10 \\
\hline [20] & SUS316+Ni1 & SUS316_10Ni & 1.4401, AISI 316 & tensile RRA & $4.2 \times 10^{-5}$ & HEE & - & 1 & 200 & 25 \\
\hline [20] & SUS316+Ni2 & SUS316_11Ni & 1.4401, AISI 316 & tensile RRA & $4.2 \times 10^{-5}$ & HEE & - & 1 & 200 & 25 \\
\hline [21] & SUS316+Mn1 & SUS316_1Mn & 1.4401, AISI 316 & tensile RRA & $4.2 \times 10^{-5}$ & HEE & - & 1 & 200 & 25 \\
\hline [21] & SUS316+Mn2 & SUS316_3Mn & exp. heat & tensile RRA & $4.2 \times 10^{-5}$ & HEE & - & 1 & 200 & 25 \\
\hline [21] & SUS316+Mn3 & SUS316_5Mn & exp. heat & tensile RRA & $4.2 \times 10^{-5}$ & HEE & - & 1 & 200 & 25 \\
\hline [21] & SUS316+Mn4 & SUS316_7Mn & exp. heat & tensile RRA & $4.2 \times 10^{-5}$ & HEE & - & 1 & 200 & 25 \\
\hline [21] & SUS316+Mn5 & SUS316_10Mn & exp. heat & tensile RRA & $4.2 \times 10^{-5}$ & HEE & - & 1 & 200 & 25 \\
\hline [3] & SUS316L & SUS316L(3) & 1.4435, AISI 316L & tensile RRA & $4.2 \times 10^{-5}$ & HEE & - & 1.1 & 200 & 10 \\
\hline [13] & SUS316L & SUS316L(1) & 1.4435, AISI 316L & tensile RRA & $2.8 \times 10^{-5}$ & HEE & - & 1 & 190 & 25 \\
\hline [20] & SUS316+Ni3 & SUS316_12Ni & 1.4401, AISI 316 & tensile RRA & $4.2 \times 10^{-5}$ & HEE & - & 1 & 200 & 25 \\
\hline
\end{tabular}


Table 1. Cont.

\begin{tabular}{|c|c|c|c|c|c|c|c|c|c|c|}
\hline \multirow[b]{2}{*}{ Reference } & \multicolumn{3}{|c|}{ Steel Designation } & \multirow{2}{*}{$\begin{array}{l}\text { Mechanical Property } \\
\text { Used to Assess HE } \\
\text { Effects }\end{array}$} & \multirow{2}{*}{$\begin{array}{c}\text { Strain Rate } \\
1 / \mathrm{s}\end{array}$} & \multirow[b]{2}{*}{$\begin{array}{l}\text { Hydrogen Charging } \\
\text { Method }\end{array}$} & \multirow{2}{*}{$\begin{array}{c}\text { H Content } \\
\text { wppm }\end{array}$} & \multirow{2}{*}{$\begin{array}{c}\text { H2 Test Pressure } \\
\text { MPa }\end{array}$} & \multirow{2}{*}{$\begin{array}{c}T_{H E, \max } \\
\mathbf{K}\end{array}$} & \multirow{2}{*}{$\begin{array}{l}\Delta \mathrm{T} \\
\mathrm{K}\end{array}$} \\
\hline & $\begin{array}{l}\text { As Given in } \\
\text { Reference }\end{array}$ & Used Here & $\begin{array}{l}\text { Equivalent } \\
\text { Grades }\end{array}$ & & & & & & & \\
\hline [3] & SUS316LN & SUS316LN & $\begin{array}{l}\text { 1.4429, AISI } \\
\text { 317LN }\end{array}$ & tensile RRA & $4.2 \times 10^{-5}$ & HEE & - & 1.1 & 200 & 10 \\
\hline [10] & SUS316L & SUS316L(4) & 1.4435, AISI 316L & tensile RRA & $4.2 \times 10^{-5}$ & HE1 & 37 & - & 200 & 25 \\
\hline [10] & SUS316 & SUS316(4) & 1.4401, AISI 316 & tensile RRA & $4.2 \times 10^{-5}$ & HE1 & 37 & - & 200 & 25 \\
\hline [10] & SUS316LN & SUS316LN & $\begin{array}{l}\text { 1.4429, AISI } \\
\text { 317LN }\end{array}$ & tensile RRA & $4.2 \times 10^{-5}$ & HE1 & 37 & - & 200 & 25 \\
\hline [3] & SUS316(S) & $316-2(S)$ & 1.4401, AISI 316 & tensile RRA & $4.2 \times 10^{-5}$ & HEE & - & 1.1 & 180 & 10 \\
\hline [14] & SUS316(S) & 316-2(S) & 1.4401, AISI 316 & tensile RRA & $4.2 \times 10^{-5}$ & HEE & - & 1 & 220 & 20 \\
\hline [21] & AISI316CW & $316 \mathrm{CW}$ & 1.4401, AISI 316 & tensile RRA & $4.2 \times 10^{-5}$ & HEE & - & 70 & 150 & 25 \\
\hline [13] & SUS304L & SUS304L(2) & 1.4306, AISI304L & tensile RRA & $2.8 \times 10^{-5}$ & HEE & - & 13 & 220 & 10 \\
\hline [13] & SUS316L & SUS316L(5) & 1.4435, AISI 316L & tensile RRA & $4.2 \times 10^{-5}$ & HEE & - & 45 & 250 & 20 \\
\hline [21] & AISI316SA & SUS316(5) & 1.4401, AISI 316 & tensile RRA & $4.2 \times 10^{-5}$ & HEE & - & 70 & 150 & 25 \\
\hline [8] & SUS316 & SUS316(3) & 1.4401, AISI 316 & tensile RRA & $5.0 \times 10^{-5}$ & HEE & - & 105 & 190 & 20 \\
\hline [21] & SUS316L & SUS316L(2) & 1.4435, AISI 316L & tensile RRA & $4.2 \times 10^{-5}$ & HEE & - & 70 & 200 & 25 \\
\hline$[7,59]$ & Nitronic-40 & $21-6-9(2)$ & 1.3965 & tensile RA & $3 \times 10^{-4}$ & HE1 & 50 & - & 250 & 25 \\
\hline$[7,59]$ & Nitronic-50 & $21-16-5$ & 1.3964 & tensile RA & $3 \times 10^{-4}$ & HE1 & 73 & - & 250 & 25 \\
\hline$[7,59]$ & Tenelon & $18-0-15$ & - & tensile RA & $3 \times 10^{-4}$ & HE1 & 57 & - & 270 & 25 \\
\hline$[9,50]$ & AISI301 & AISI301 & 1.4310, SUS 301 & $(\mathrm{da} / \mathrm{dt})_{\mathrm{II}}$ & - & HEE & - & 0.108 & 350 & 25 \\
\hline [23] & 1.4581 & 1.4581 & - & $\mathrm{da} / \mathrm{dN}$ & - & HEE & - & 10 & - & - \\
\hline
\end{tabular}




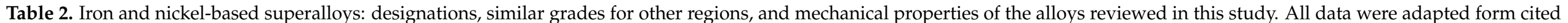

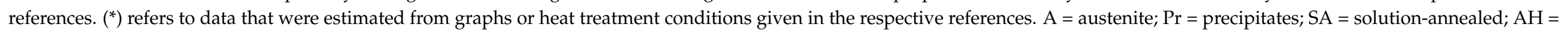

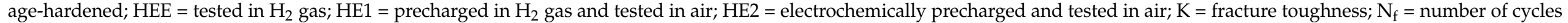
to failure in Wöhler-type fatigue life tests; $\varepsilon_{\mathrm{f}}=$ tensile elongation at fracture.

\begin{tabular}{|c|c|c|c|c|c|c|c|c|c|c|c|c|c|}
\hline \multirow{2}{*}{ Alloy Class } & \multirow{2}{*}{ Reference } & \multicolumn{2}{|c|}{ Alloy Designation } & \multirow{2}{*}{ Microstructure } & \multirow{2}{*}{$\begin{array}{c}\text { Heat } \\
\text { Treatment }\end{array}$} & \multirow{2}{*}{$\begin{array}{c}\begin{array}{c}\text { UTS in } \\
\text { Ambient Air }\end{array} \\
\text { MPa }\end{array}$} & \multirow{2}{*}{$\begin{array}{l}\text { Mechanical Property } \\
\text { Used to Assess HE } \\
\text { Effects }\end{array}$} & \multirow{2}{*}{$\begin{array}{c}\text { Strain Rate } \\
1 / \mathrm{s}\end{array}$} & \multirow{2}{*}{$\begin{array}{c}\text { Hydrogen } \\
\text { Charging Method }\end{array}$} & \multirow{2}{*}{$\begin{array}{c}\text { H Content } \\
\text { wppm }\end{array}$} & \multirow{2}{*}{$\begin{array}{c}\begin{array}{c}\mathbf{H}_{2} \text { Test } \\
\text { Pressure }\end{array} \\
\text { MPa }\end{array}$} & \multirow{2}{*}{$\frac{T_{H E, \max }}{\mathrm{K}}$} & \multirow{2}{*}{$\begin{array}{r}\Delta \mathrm{T} \\
\mathrm{K}\end{array}$} \\
\hline & & $\begin{array}{l}\text { As Given in } \\
\text { Reference }\end{array}$ & $\begin{array}{l}\text { Equivalent } \\
\text { Grades * }\end{array}$ & & & & & & & & & & \\
\hline \multirow{7}{*}{ 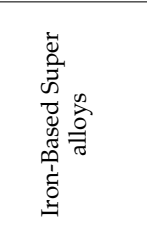 } & {$[7,59]$} & AISI310 & $\begin{array}{l}1.4841 \\
\text { SUS310 }\end{array}$ & A & SA & 500 & tensile RA & $3 \times 10^{-4}$ & HE1 & 37 & - & 270 & 10 \\
\hline & {$[7,59]$} & Incoloy $800 \mathrm{H}$ & 1.4876 & $\mathrm{~A}+\operatorname{Pr}$ & $\mathrm{AH}$ & 820 & tensile RA & $3 \times 10^{-4}$ & HE1 & 25 & - & 270 & 10 \\
\hline & [26] & SUH660 & 1.4980, A286 & $A+\operatorname{Pr}$ & $\mathrm{AH}$ & $1100 *$ & tensile RA & $4.2 \times 10^{-5}$ & HE1 & 37 & - & $>290$ & 25 \\
\hline & {$[18]$} & JBK75 & 1.4980, A286 & $A+\operatorname{Pr}$ & $\mathrm{AH}$ & $1790 *$ & tensile RA & $3.4 \times 10^{-4}$ & HE1 & 55 & - & 290 & 50 \\
\hline & [19] & $16 \mathrm{Cr} 75 \mathrm{Ni}$ & exp. heat & A & SA & na & tensile RA & $1.7 \times 10^{-1}$ & HE2 & $18-29$ & - & 220 & 30 \\
\hline & [19] & $20 \mathrm{Cr} 25 \mathrm{Ni}$ & exp. heat & A & SA & na & tensile RA & $3 \times 10^{-4}$ & HE2 & - & - & $>290$ & 40 \\
\hline & [19] & $20 \mathrm{Cr} 35 \mathrm{Ni}$ & exp. heat & A & SA & na & tensile RA & $3 \times 10^{-4}$ & HE2 & - & - & $>290$ & 40 \\
\hline \multirow{5}{*}{ 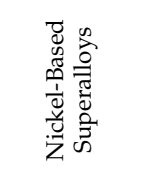 } & [60] & Inc718(3) & 2.4668 & $A+\operatorname{Pr}$ & $\mathrm{AH}$ & na & tensile RA & na & HEE & - & 51.7 & 320 & 25 \\
\hline & [60] & $\operatorname{Inc} 718(3)$ & 2.4668 & $A+\operatorname{Pr}$ & $\mathrm{AH}$ & na & $\mathrm{N}_{\mathrm{f}}$ at $2 \%$ strain & (1) & HEE & - & 34.5 & 298 & 80 \\
\hline & [4] & Inc718(2) & 2.4668 & $A+\operatorname{Pr}$ & $\mathrm{AH}$ & 1420 & $\mathrm{~K}_{\mathrm{H}}$ & & HEE & - & 34.5 & 298 & 20 \\
\hline & [25] & Inc718(1) & 2.4668 & $A+\operatorname{Pr}$ & $\mathrm{AH}$ & 1466 & tensile $\varepsilon_{\mathrm{f}}$ & $5.0 \times 10^{-4}$ & HE2 & - & - & 295 & 30 \\
\hline & [4] & Udimet 700 & - & $A+\operatorname{Pr}$ & $\mathrm{AH}$ & 1262 & notched UTS & $1.1 \times 10^{-3}$ & HEE & - & 27.5 & 390 & 50 \\
\hline \multirow{3}{*}{ 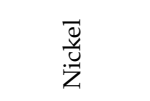 } & {$[28,61]$} & $\mathrm{Ni}(1)$ & - & A & SA & na & tensile RA & $3.3 \times 10^{-5}$ & HEE & - & 8.3 & 290 & 50 \\
\hline & [29] & $\mathrm{Ni}(2)$ & - & A & SA & $390 *$ & tensile $\varepsilon_{\mathrm{f}}$ & $1.7 \times 10^{-3}$ & HE2 & - & - & 220 & 20 \\
\hline & [29] & $\mathrm{Ni}(2)$ & - & A & SA & $390 *$ & tensile $\varepsilon_{\mathrm{f}}$ & $3.3 \times 10^{-5}$ & HE2 & - & - & 220 & 20 \\
\hline
\end{tabular}

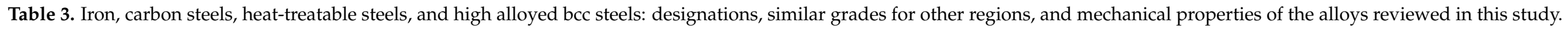

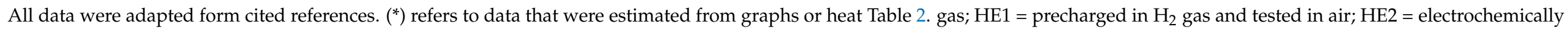

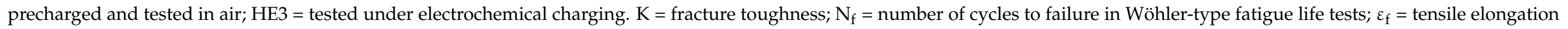
at fracture; $\varphi_{\mathrm{f}}=$ tensile true fracture strain; $\sigma_{\mathrm{f}}=$ tensile true fracture stress.

\begin{tabular}{|c|c|c|c|c|c|c|c|c|c|c|c|c|}
\hline \multirow{2}{*}{ Steel Class } & \multirow{2}{*}{ Reference } & \multicolumn{2}{|c|}{ Steel Designation } & \multirow{2}{*}{ Microstructure } & \multirow{2}{*}{$\begin{array}{c}\begin{array}{c}\text { UTS in } \\
\text { Ambient Air }\end{array} \\
\text { MPa }\end{array}$} & \multirow{2}{*}{$\begin{array}{l}\text { Mechanical Property } \\
\text { Used to Assess HE } \\
\text { Effects }\end{array}$} & \multirow{2}{*}{$\begin{array}{c}\text { Strain Rate } \\
1 / \mathrm{s}\end{array}$} & \multirow{2}{*}{$\begin{array}{c}\text { Hydrogen } \\
\text { Charging } \\
\text { Method }\end{array}$} & \multirow{2}{*}{$\begin{array}{c}\begin{array}{c}\mathrm{H} \\
\text { Content }\end{array} \\
\text { wppm } \\
\end{array}$} & \multirow{2}{*}{$\begin{array}{c}\begin{array}{c}\mathrm{H}_{2} \text { Test } \\
\text { Pressure }\end{array} \\
\mathrm{MPa} \\
\end{array}$} & \multirow{2}{*}{$\frac{T_{H E, \max }}{\mathbf{K}}$} & \multirow{2}{*}{$\begin{array}{r}\Delta \mathrm{T} \\
\mathrm{K}\end{array}$} \\
\hline & & As Given in Reference & Equivalent Grades & & & & & & & & & \\
\hline ₹ & [30] & SUY & $1.08 \mathrm{xx}$ & $\mathrm{F}$ & 310 & tensile RRA & $4.2 \times 10^{-5}$ & HEE & - & 1.1 & 200 & 25 \\
\hline 의 & [31] & $\mathrm{Fe}$ & $1.08 \mathrm{xx}, \mathrm{SUY}$ & $\mathrm{F}$ & 252 & tensile RA & $1.1 \times 10^{-3}$ & HE2 & na & - & 300 & - \\
\hline
\end{tabular}


Table 3. Cont.

\begin{tabular}{|c|c|c|c|c|c|c|c|c|c|c|c|c|}
\hline \multirow{2}{*}{ Steel Class } & \multirow{2}{*}{ Reference } & \multicolumn{2}{|c|}{ Steel Designation } & \multirow{2}{*}{ Microstructure } & \multirow{2}{*}{$\begin{array}{c}\begin{array}{c}\text { UTS in } \\
\text { Ambient Air }\end{array} \\
\text { MPa }\end{array}$} & \multirow{2}{*}{$\begin{array}{c}\text { Mechanical Property } \\
\text { Used to Assess HE } \\
\text { Effects }\end{array}$} & \multirow{2}{*}{$\begin{array}{c}\text { Strain Rate } \\
1 / \mathrm{s} \\
\end{array}$} & \multirow{2}{*}{$\begin{array}{l}\text { Hydrogen } \\
\text { Charging } \\
\text { Method }\end{array}$} & \multirow{2}{*}{$\begin{array}{c}\begin{array}{c}\mathbf{H} \\
\text { Content }\end{array} \\
\text { wppm } \\
\end{array}$} & \multirow{2}{*}{$\begin{array}{c}\begin{array}{c}\mathrm{H}_{2} \text { Test } \\
\text { Pressure }\end{array} \\
\mathrm{MPa} \\
\end{array}$} & \multirow{2}{*}{$\begin{array}{c}T_{H E, \max } \\
\mathbf{K}\end{array}$} & \multirow{2}{*}{$\begin{array}{l}\Delta \mathrm{T} \\
\mathrm{K} \\
\end{array}$} \\
\hline & & As Given in Reference & Equivalent Grades & & & & & & & & & \\
\hline \multirow{13}{*}{ 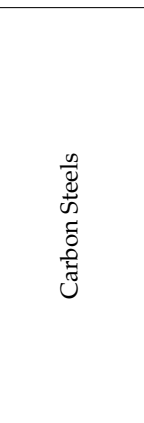 } & [32] & SM490B & 1.0570, ASTM A678 Gr. B & $\mathrm{F}+\mathrm{P}^{*}$ & 537 & tensile RRA & $6.7 \times 10^{-5}$ & HEE & - & 115 & $<230$ & 40 \\
\hline & [30] & S15C & 1.1141, AISI1015 & $F+P$ & 490 & tensile RRA & $4.2 \times 10^{-5}$ & HEE & - & 1.1 & 200 & 25 \\
\hline & [30] & $\mathrm{S} 35 \mathrm{C}$ & 1.1181, AISI1035 & $\mathrm{F}+\mathrm{P}$ & 560 & tensile RRA & $4.2 \times 10^{-5}$ & HEE & - & 1.1 & 200 & 25 \\
\hline & [5] & Ck22 cold formed & 1.1151, AISI1022, S22C & $\mathrm{F}+\mathrm{P}$ & 630 & tensile RA & $8.3 \times 10^{-4}$ & HEE & - & 15 & 270 & 20 \\
\hline & [5] & Ck22 normalized & 1.1151, AISI1022, S22C & $F+P$ & 531 & tensile RA & $8.3 \times 10^{-4}$ & HEE & - & 15 & 220 & 20 \\
\hline & [33] & St3 & 1.0038, AISI1008, SS400 & $\mathrm{F}+\mathrm{P}^{*}$ & 280 & tensile $\sigma_{\mathrm{f}}$ & na & HE1 & 6.3 & - & 370 & - \\
\hline & [34] & SAE 1020 & $1.1151, \mathrm{~S} 20 \mathrm{C}$ & $\mathrm{F}+\mathrm{Fe}_{3} \mathrm{C}^{*}$ & 432 & tensile $\varphi_{\mathrm{f}}$ & $8.3 \times 10^{-4}$ & HE2 & - & - & 260 & 20 \\
\hline & [34] & SAE 1020 & $1.1151, \mathrm{~S} 20 \mathrm{C}$ & $\mathrm{F}+\mathrm{Fe}_{3} \mathrm{C}^{*}$ & 432 & tensile $\varphi_{\mathrm{f}}$ & $1.6 \times 10^{-1}$ & HE2 & - & - & 270 & 20 \\
\hline & [35] & SAE 1020 & 1.1151, S20C & $\mathrm{F}+\mathrm{Fe}_{3} \mathrm{C}^{*}$ & 432 & tensile $\varphi_{\mathrm{f}}$ & $8.3 \times 10^{-3}$ & HE2 & - & - & 220 & 10 \\
\hline & {$[36,39]$} & AISI4130 & 1.7220, SCM435 & $\mathrm{TM}^{*}$ & 1517 & $(\mathrm{da} / \mathrm{dt})_{\mathrm{II}}$ & - & HEE & - & 0.09 & 280 & 10 \\
\hline & [37] & AISI4130 & 1.7220, SCM435 & $\mathrm{TM}^{*}$ & 1500 & $(\mathrm{da} / \mathrm{dt})_{\text {II }}$ & - & HEE & - & 0.08 & 320 & 20 \\
\hline & [37] & AISI4130 & 1.7220, SCM435 & $\mathrm{TM}^{*}$ & 1300 & $(\mathrm{da} / \mathrm{dt})_{\text {II }}$ & - & HEE & - & 0.08 & 280 & 20 \\
\hline & [62] & HP-9-4-20 & - & $\mathrm{TM}^{*}$ & 1480 & $\mathrm{da} / \mathrm{dN}$ & - & HEE & - & 0.013 & 270 & 30 \\
\hline \multirow{16}{*}{ 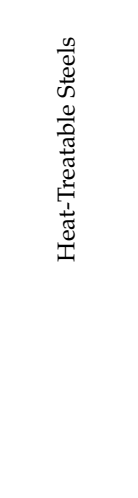 } & [38] & 30CrMnSi-Ni2A & - & $\mathrm{TM}^{*}$ & 1813 & $\mathrm{~K}_{\mathrm{H}}$ & - & HEE & - & 0.101 & 320 & 15 \\
\hline & [39] & AISI4130 & 1.7220, SCM435 & $\mathrm{TM} *$ & 1517 & $\mathrm{~K}_{\mathrm{H}}$ & - & HEE & - & 0.09 & 290 & 20 \\
\hline & [40] & AISI4340 & 1.6511, SNCM439 & $\mathrm{TM}^{*}$ & 1338 & $\mathrm{~K}_{\mathrm{H}}$. & - & HEE & - & 0.55 & 270 & 20 \\
\hline & {$[27]$} & UNI40NiCrMo7 & 1.6562, AISI4340 & $\mathrm{M}$ & 2050 & time to failure & - & HE2 & - & - & 295 & 30 \\
\hline & {$[63,64]$} & 2.25Cr-1Mo steel & $1.7380, \sim S A 542-3$ & $F+B^{*}$ & $580-650$ & $\mathrm{~K}_{\mathrm{H}}$ & - & HE1 & 5 & - & $<220$ & 25 \\
\hline & [32] & SCM435 & 1.7220, AISI4130 & $\mathrm{TM}^{*}$ & 824 & tensile RRA & $6.7 \times 10^{-5}$ & HEE & - & 115 & $<230$ & 40 \\
\hline & [13] & SCM435 & 1.7220, AISI4130 & $\mathrm{TM}^{*}$ & 820 & tensile RRA & $4 \times 10^{-4}$ & HEE & - & 13 & 220 & 40 \\
\hline & [13] & SCM435 & 1.7220, AISI4130 & $\mathrm{TM}^{*}$ & 820 & tensile RRA & $4 \times 10^{-4}$ & HEE & - & 70 & $>290$ & 50 \\
\hline & {$[42,43]$} & $3 \mathrm{Cr}-0,5 \mathrm{Mo}$ steel & $\sim 1.7361$ & $\mathrm{~F}+\mathrm{P}^{*}$ & 565 & tensile RA & $4.4 \times 10^{-2}$ & HE2 & 3.8 & - & 290 & 40 \\
\hline & {$[42,43]$} & $3 \mathrm{Cr}-0,5 \mathrm{Mo}$ steel & $\sim 1.7361$ & $\mathrm{~F}+\mathrm{P}^{*}$ & 724 & tensile RA & $4.4 \times 10^{-2}$ & HE2 & 4 & - & 190 & 40 \\
\hline & {$[44]$} & C-Mn steel & - & $\mathrm{TM} *$ & 1850 & tensile RA & $8.3 \times 10^{-4}$ & HE2 & 1 & - & 250 & 25 \\
\hline & [44] & C-Mn steel & - & $\mathrm{TM}^{*}$ & 1850 & tensile RA & $8.3 \times 10^{-4}$ & HE2 & 1.3 & - & 250 & 25 \\
\hline & [44] & C-Mn steel & - & $\mathrm{TM}^{*}$ & 1850 & tensile RA & $8.3 \times 10^{-4}$ & HE2 & 1.5 & - & 300 & 25 \\
\hline & [45] & SUS630 & $1.4542,17-4 \mathrm{PH}$ & $\mathrm{TM}+\mathrm{Pr}$ & 1300 & tensile RRA & $2.8 \times 10^{-5}$ & HEE & - & 10 & 230 & 25 \\
\hline & [45] & SUS630 & $1.4542,17-4 \mathrm{PH}$ & $\mathrm{TM}+\mathrm{Pr}$ & 1300 & tensile RRA & $2.8 \times 10^{-5}$ & HEE & - & 70 & 230 & 25 \\
\hline & [13] & SUS630 & $1.4542,17-4 \mathrm{PH}$ & $\mathrm{TM}+\mathrm{Pr}$ & 1140 & tensile RRA & $4 \times 10^{-4}$ & HEE & - & 13 & 230 & 20 \\
\hline \multirow{14}{*}{ 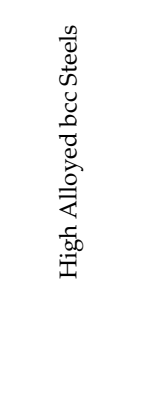 } & [13] & SUS630 & $1.4542,17-4 \mathrm{PH}$ & $\mathrm{TM}+\operatorname{Pr}$ & 1140 & tensile RRA & $4 \times 10^{-4}$ & HEE & - & 70 & 230 & 20 \\
\hline & [13] & SUS430 & 1.4016, AISI430 & $\mathrm{F}^{*}$ & 480 & tensile RRA & $4 \times 10^{-4}$ & HEE & - & 13 & 230 & 20 \\
\hline & [13] & SUS430 & 1.4016, AISI430 & $\mathrm{F}^{*}$ & 480 & tensile RRA & $4 \times 10^{-4}$ & HEE & - & 70 & 190 & 20 \\
\hline & [65] & H-11 & 1.2343, SKD6 & $\mathrm{TM}+\operatorname{Pr}$ & 1900 & tensile RA & $1.1 \times 10^{-3}$ & HEE & - & 0.02 & 200 & 30 \\
\hline & [46] & Kh16N6 & exp. heat & $A+M$ & 3217 & $\mathrm{~N}_{\mathrm{f}}$ at $1.6 \%$ strain & - & HEE & - & 0.103 & $<290$ & 80 \\
\hline & {$[47,51]$} & H-11 & 1.2343, SKD6 & $\mathrm{TM}+\operatorname{Pr}$ & 1880 & $(\mathrm{da} / \mathrm{dt})_{\mathrm{II}}$ & - & HEE & - & 0.1 & 300 & 40 \\
\hline & {$[48]$} & $18 \mathrm{Ni}(200)$ & $\sim 1.2709$ & $\mathrm{TM}+\mathrm{Pr}$ & 1330 & $(\mathrm{da} / \mathrm{dt})_{\mathrm{II}}$ & - & HEE & - & 0.133 & 250 & 20 \\
\hline & [48] & $18 \mathrm{Ni}(200)$ & $\sim 1.2709$ & $\mathrm{TM}+\mathrm{Pr}$ & 1330 & $(\mathrm{da} / \mathrm{dt})_{\mathrm{II}}$ & - & HEE & - & 0.266 & 260 & 20 \\
\hline & [48] & $18 \mathrm{Ni}(250)$ & $\sim 1.2709$ & $\mathrm{TM}+\mathrm{Pr}$ & 1720 & $(\mathrm{da} / \mathrm{dt})_{\text {II }}$ & - & HEE & - & 0.012 & 250 & 20 \\
\hline & [48] & $18 \mathrm{Ni}(250)$ & $\sim 1.2709$ & $\mathrm{TM}+\mathrm{Pr}$ & 1720 & $(\mathrm{da} / \mathrm{dt})_{\mathrm{II}}$ & - & HEE & - & 0.028 & 270 & 20 \\
\hline & [48] & $18 \mathrm{Ni}(250)$ & $\sim 1.2709$ & $\mathrm{TM}+\mathrm{Pr}$ & 1720 & $(\mathrm{da} / \mathrm{dt})_{\mathrm{II}}$ & - & HEE & - & 0.057 & 280 & 20 \\
\hline & [48] & $18 \mathrm{Ni}(250)$ & $\sim 1.2709$ & $\mathrm{TM}+\mathrm{Pr}$ & 1720 & $(\mathrm{da} / \mathrm{dt})_{\mathrm{II}}$ & - & HEE & - & 0.133 & 300 & 20 \\
\hline & [49] & $18 \mathrm{Ni}(300)$ & $\sim 1.2709$ & $\mathrm{TM}+\operatorname{Pr}$ & 1977 & $(\mathrm{da} / \mathrm{dt})_{\mathrm{II}}$ & - & HEE & - & 0.133 & 320 & 30 \\
\hline & {$[9,50]$} & AL29-4-2 & - & $\mathrm{F}^{*}$ & 550 & $(\mathrm{da} / \mathrm{dt})_{\text {II }}$ & - & HEE & - & 0.108 & 320 & 25 \\
\hline
\end{tabular}




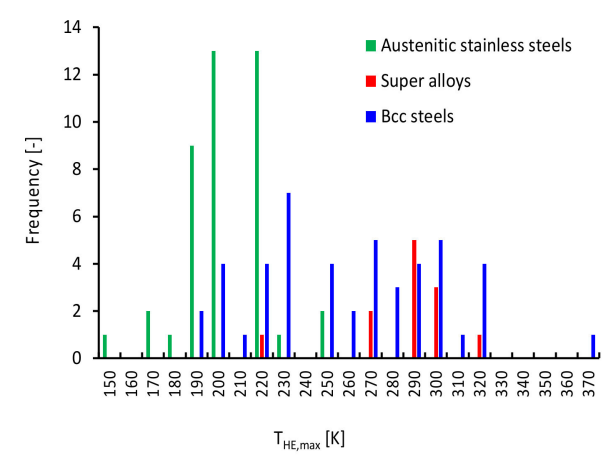

(a)

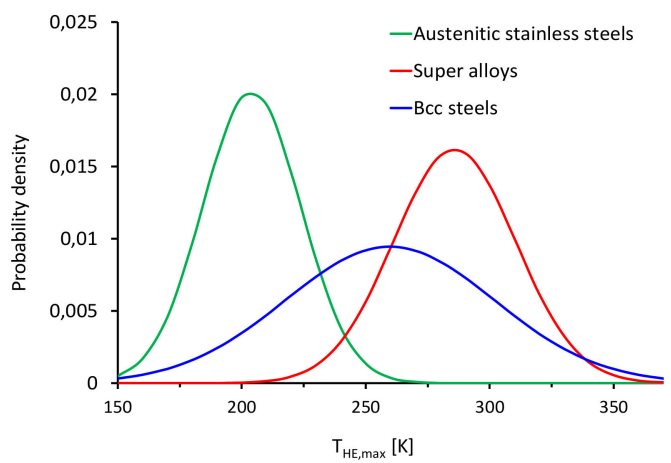

(b)

Figure 7. (a) Histograms of the reviewed datasets for austenitic stainless steels (excluding CrMnN steels and cold-worked austenitic steels), iron-based and nickel-based superalloys (excluding pure nickel and Udimet 700), and bcc steels; (b) corresponding probability density functions (Gaussian plots).

For austenitic stainless steels, it can be deducted from Figure $7 \mathrm{~b}$ that about $95 \%$ (mean value \pm two times the standard deviation) of the experimental data lay between 165 and $244 \mathrm{~K}$. Considering a mean error of $20 \mathrm{~K}$ of the individual experimental data (Figure 3), setting $T_{H E, \max }=205 \mathrm{~K}$ for austenitic steels appears to be feasible to capture the worst-case hydrogen effects in austenitic stainless steel designs.

For iron-based and nickel-based superalloys, $95 \%$ of the experimental data lay between 239 and $335 \mathrm{~K}$ (Figure $7 \mathrm{~b}$ ). Given the very limited number of experimental results, a recommendation of characteristic $T_{H E \text {, } \max }$ value for this alloy class does not appears to be feasible. However, since the mean value of $286 \mathrm{~K}$ is close to room temperature, room temperature appears to be a suitable start temperature to study temperature effects.

For bcc steels, 95\% of the experimental data lay between 175 and $345 \mathrm{~K}$ (Figure 7b). Due to this very large range, a recommendation of a characteristic $T_{H E \text {, max }}$ value for this alloy class is not possible with the available data. This large standard deviation may partly be caused by a superposition of two mechanisms, i.e., hydrogen effects and low temperature embrittlement, since the ductile-to-brittle transition temperature was found to vary significantly among the bcc steels reviewed here. In addition, the bcc steels generally include a wide variety of microstructures, e.g., ferrite, pearlite, bainite, and martensite, as well as variations (e.g., lower/upper bainite) and combinations (e.g., ferrite-pearlite) thereof. Generally, bcc steels are alloyed with special alloying elements to allow for the production of the individual microstructures when using adapted heat treatments. It is very likely that the kinetics of the temperature-dependent hydrogen effects are different among the individual microstructures, which is likely to be another reason for the large scattering of the $T_{H E, \max }$ values.

\section{Conclusions}

This review and analysis of the temperature of maximum hydrogen effects $\left(T_{H E, \max }\right)$ in structural alloys can be summarized as follows:

Austenitic stainless steels: quite consistent results of $T_{H E, \max }$ values around $205 \mathrm{~K}$ have been reported. A result from a single study suggests a variation of $T_{H E, \max }$ depending on the test method (sustained crack growth, and cyclic crack growth). This needs to be further investigated.

Iron- and nickel-based superalloys: the limited number of results suggest $T_{H E, \max }$ values around room temperature. No significant difference between solution-annealed single phase austenitic microstructures and age-hardened austenitic plus precipitation microstructures could be identified. Inconel 718 showed no variation of $T_{H E, \max }$ depending 
on the test method. The difference of about $100 \mathrm{~K}$ in $T_{H E \text {, max }}$ values compared to austenitic stainless steels despite comparable microstructures needs to be further investigated.

Bcc steels: bcc steels showed large scatter in $T_{H E \text {, max }}$ values, possibly due to the large variation of microstructures and a superposition of low-temperature embrittlement effects.

Some single study results, like those of pure nickel and $\mathrm{CrMnN}$ austenitic steels, are also difficult to interpret. It can be concluded that the kinetics of hydrogen effects in structural alloys need to be investigated and understood in much more detail to properly interpret the experimental results.

Author Contributions: Conceptualization, T.M.; data curation, T.M.; writing-original draft preparation, T.M.; writing-review and editing, F.S. and K.W. All authors have read and agreed to the published version of the manuscript.

Funding: This research received no external funding.

Institutional Review Board Statement: Not applicable.

Informed Consent Statement: Not applicable.

Data Availability Statement: Not applicable.

Conflicts of Interest: The authors declare no conflict of interest.

\section{References}

1. Office of the European Union. Hydrogen Roadmap Europe-A Sustainable Pathway for the European Energy Transition, Fuel Cells and Hydrogen 2 Joint Undertaking; Publications Office of the European Union: Luxembourg, 2019.

2. Johnson, W.H., II. On some remarkable changes produced in iron and steel by the action of hydrogen and acids. Proc. R. Soc. Lond. 1875, 23, 168-179. [CrossRef]

3. Fukuyama, S.; Sun, D.; Zhang, L.; Wen, M.; Yokogawa, K. Effect of temperature on hydrogen environment embrittlement of type 316 series austenitic stainless steels at low temperatures. J. Jpn. Inst. Metal 2003, 67, 456-459. [CrossRef]

4. Frick, F.; Janser, G.R.; Brown, J.A. Enhanced Flaw Growth in SSE Main Engine Alloys in High Pressure Gaseous Hydrogen; Sp. Shuttle Mater.: Azusa, CA, USA, 1971; pp. 579-634.

5. Hofmann, W.; Rauls, W. Ductility of steel under the influence of external high pressure hydrogen. Weld. Res. Suppl. 1965, 5, 225-230.

6. Borchers, C.; Michler, T.; Pundt, A. Effect of Hydrogen on the Mechanical Properties of Stainless Steels. Adv. Eng. Mater. 2008, 10, 11-23. [CrossRef]

7. Caskey, G.J. Hydrogen compatibility handbook for stainless steels. In Hydrogen Compatibility Handbook for Stainless Steels; Office of Scientific and Technical Information (OSTI): Oak Ridge, TN, USA, 1983; p. 160.

8. Iijima, T.; Enoki, H.; Yamabe, J.; An, B. Effect of high pressure gaseous hydrogen on fatigue properties of SUS304 and SUS316 austenitic stainless steel. In Proceedings of the ASME 2018 Pressure Vessels and Piping Conference (PVP2018), Prague, Czech Republic, 15-20 July 2018; p. PVP2018-84267. [CrossRef]

9. Perng, T.P.; Altstetter, C.J. Comparison of hydrogen gas embrittlement of austenitic and ferritic stainless steels. Metal Mater. Trans. A 1987, 18, 123-134. [CrossRef]

10. Zhang, L.; Imade, M.; An, B.; Wen, M.; Iijima, T.; Fukuyama, S.; Yokogawa, K. Internal Reversible Hydrogen Embrittlement of Austenitic Stainless Steels Based on Type 316 at Low Temperatures. ISIJ Int. 2012, 52, 240-246. [CrossRef]

11. Sun, D.; Han, G.; Vaodee, S.; Fukuyama, S.; Yokogawa, K. Tensile behaviour of type 304 austenitic stainless steels in hydro-gen atmosphere at low temperatures. Mater. Sci. Technol. 2001, 17, 302-308. [CrossRef]

12. Fukuyama, S.; Sun, D.; Yokogawa, K. Effect of Temperature on Hydrogen Environment Embrittlement of Niobium. J. Jpn. Inst. Metal 2001, 65, 783-786. [CrossRef]

13. National Institute of Advanced Industrial Science and Technology. 2010 Oil Refining Industry Security Measures Project: RED on Material Usage Standards Associated with Hydrogen Energy Utilization; J. New Energy, Industrial Technology Development Organization (NEDO), Eds.; National Institute of Advanced Industrial Science and Technology (AIST): Ibaraki, Japan, 2011.

14. Han, G.; He, S.; Fukuyama, S.; Yokogawa, K. Effect of Nickel Equivalent on Hydrogen Environment Embrittlement of Aus-tenitc Stainless Steels at Low Temperatures. Acta Mater. 1998, 46, 4570-4599. [CrossRef]

15. Imade, M.; Iijima, T.; Fukuyama, S.; Yokogawa, K. Effect of Heat-Treatment on High-Pressure Hydrogen Gas Embrittlement of Austenitic Stainless Steels. J. Jpn. Inst. Metal 2008, 72, 139-145. [CrossRef]

16. Krylov, V.P.; Anisimova, M.S.; Panov, V.I. Structure and resistance to deformation of hydrogenated steel $12 \mathrm{Kh} 18 \mathrm{Ni} 10 \mathrm{~T}$ at different temperatures. Metal Sci. Heat Treat. 1980, 22, 721-723. [CrossRef]

17. Zhang, L.; An, B.; Iijima, T.; Marchi, C.S.; Somerday, B. Hydrogen Transport and Hydrogen-Assisted Cracking in SUS304 Stainless Steel During Deformation at Low Temperatures. In Proceedings of the ASME 2015 Pressure Vessels and Piping Conference, Boston, MA, USA, 19-23 July 2015; pp. 2015-45211. 
18. Holbrook, J.H.; West, A.J. The effect of temperature and strain rate on the tensile peroperties of hydrogen charged 304L, 21-6-9 and JBK75. In Proceedings of the 3rd International Conference on Effect of Hydrogen on the Behaviour of Materials, Moran, WY, USA, 26-31 August 1980; pp. 655-663.

19. Lagneborg, R. Hydrogen embrittlement in austenitic steels and Nickel-base alloys. J. Iron Steel Inst. 1969, 3, 363-366.

20. Zhang, L.; Wen, M.; Imade, M.; Fukuyama, S.; Yokogawa, K. Effect of nickel equivalent on hydrogen gas embrittlement of austenitic stainless steels based on type 316 at low temperatures. Acta Mater. 2008, 56, 3414-3421. [CrossRef]

21. AIST. 2011 Oil Refining Industry Security Measures Project. RED on Material Usage Standards Associated with Hydrogen Energy Utilization; J. New Energy, Industrial Technology Development Organization (NEDO), Eds.; National Institute of Advanced Industrial Science and Technology (AIST): Ibaraki, Japan, 2012.

22. Michler, T.; Lindner, M.; Eberle, U.; Meusinger, J. Assessing hydrogen embrittlement in automotive hydrogen tanks. In Gaseous Hydrogen Embrittlement of Materials in Energy Technologies; Woodhead Publishing: Oxford, MI, USA; Cambridge, MA, USA; Philadelphia, PA, USA; New Delhi, India, 2012; pp. 94-125.

23. Deimel, P.; Sattler, E. Untersuchungen zum Wasserstoffeinfluss auf im Kompressorbau Eingesetzte Werkstoffe; Forschungskuratorium Maschinenbau: Frankfurt, Germany, 2007. (In Germany)

24. Fritzemeier, L.G.; Chandler, W.T. Hydrogen Embrittlement-Rocket Engine Applications; Tien, J.K., Caufield, T., Eds.; Academic Press: London, UK, 1989; pp. 491-524.

25. Odemer, G.; Andrieu, E.; Blanc, C.; Cloue, J.-M.; Galliano, F. Effect of Metallurgical State and Temperature on the Hydrogen Embrittlement Susceptibility of Alloy 718. In Proceedings of the International Hydrogen Conference (IHC 2012): HydrogenMaterials Interactions, Jackson Lake Lodge, WY, USA, 9-12 September 2014; pp. 421-430.

26. Imade, M.; Zhang, L.; Iijima, T.; Fukuyama, S.; Yokogawa, K. Effect of Temperature on Internal Reversible Hydrogen Embrittlement of SUH660 Iron-Based Superalloy and Austenitic Stainless Steels at Low Temperature. J. Jpn. Inst. Metal 2009, 73, 245-250. [CrossRef]

27. Quadrini, E. The effect of temperature on hydrogen induced fracture in UNI 40NiCrM07 steel. Mater. Chem. Phys. 1988, 20, 73-85. [CrossRef]

28. Jewett, R.P.; Walter, R.J.; Chandler, W.T.; Frohmberg, R.P. Hydrogen Environment Embrittlement of Metals. In NASA-CR-2163; NASA: Washington, DC, USA, 1973; p. 238.

29. Boniszewski, T.; Smith, G. The influence of hydrogen on the plastic deformation ductility, and fracture of nickel in tension. Acta Metal 1963, 11, 165-178. [CrossRef]

30. Zhang, L.; Wen, M.; Fukuyama, S.; Yokogawa, K. Effect of Temperature on Hydrogen Environment Embrittlement of Carbon Steels at Low Temperatures. J. Jpn. Inst. Metal 2003, 67, 460-463. [CrossRef]

31. Krylov, V.P. Anomalies in the deformability of degasses metals at temperatures of reversibls hydrogen embrittlement. Metal Sci. Heat Treat. 1995, 37, 495-498. [CrossRef]

32. Matsunaga, H.; Yoshikawa, M.; Kondo, R.; Yamabe, J.; Matsuoka, S. Slow strain rate tensile and fatigue properties of Cr-Mo and carbon steels in a $115 \mathrm{MPa}$ hydrogen gas atmosphere. Int. J. Hydrogen Energy 2015, 40, 5739-5748. [CrossRef]

33. Pokhodnya, I.K.; Shvachko, V.I. Nature of hydrogen embrittlement of structural steels. Mater. Sci. 2001, 37, 241-251. [CrossRef]

34. Smialowski, M. Hydrogen in Steel; Pergamon Press: Oxford, UK, 1962.

35. Toh, T.; Baldwin, W.M. Ductility of steel with vaying concentrations of hydrogen. In Stress Corros Crack Embrittlement; Robertson, W.D., Ed.; John Wiley \& Sons: New York, NY, USA, 1956; pp. 176-186.

36. Williams, D.P.; Nelson, H.G. Embrittlement of 4130 steel by low pressure gaseous hydrogen. Metall. Trans. 1970, 1, 63-68.

37. Nelson, H.G.; Williams, D.P. Quantitative Observations of Hydrogen-Induced, Slow Crack Growth in a Low Alloy Steel; Series NACE-5; NASA: Houston, TX, USA, 1977; pp. 390-404.

38. Tan, S.M.; Gao, S.J.; Wan, X.J. Temperature effects on gaseous hydrogen embrittlement of a high-strength steel. J. Mater. Sci. Lett. 1993, 12, 643-646. [CrossRef]

39. Nelson, H.G.; Williams, D.P.; Tetelman, A.S. Embrittlement of a ferrous alloy in a partially dissociated hydrogen environment. Metal Mater. Trans. A 1971, 2, 953-959. [CrossRef]

40. Clark, W.G. Effect of temperature and pressure on hydrogen cracking in high strength type 4340 steel. J. Mater. Energy Syst. 1979, 1, 33-40. [CrossRef]

41. Xing, X.; Cheng, R.; Cui, G.; Liu, J.; Gou, J.; Yang, C.; Li, Z.; Yang, F. Quantification of the temperature threshold of hydrogen embrittlement in X90 pipeline steel. Mater. Sci. Eng. A 2021, 800, 140118. [CrossRef]

42. Hobson, J.D.; Sykes, C. Effect of hydrogen on the properties of low-alloy steels. J. Iron Steel Inst. 1951, 169, 209-220.

43. Hobson, J.D.; Hewitt, J. The effect of hydrogen on the tensile properties of steel. J. Iron Steel Inst. 1953, 173, 131-140.

44. Farrell, K.; Quarrell, A.G. Hydrogen embrittlement of an ultra-high-tensile steel. J. Iron Steel Inst. 1964, 12, 1002-1011.

45. Ogata, T. Influence of $70 \mathrm{MPa}$ Hydrogen Gas on SUS 630 From $77 \mathrm{~K}$ to $373 \mathrm{~K}$ by Simple Testing Method. In Proceedings of the ASME 2018 Pressure Vessels and Piping Conference, Prague, Czech Republic, 15-20 July 2018; pp. 2018-84462. [CrossRef]

46. Romaniv, A.N.; Tkachev, V.I.; Starinskii, V.D.; Duryagin, V.A.; Alymov, V.T. Low-cycle strength of steel Kh16N6 in a gase-ous hydrogen environment. Mater. Sci. 1978, 13, 532-534. [CrossRef]

47. Johnson, H.H. Hydrogen brittleness in hydrogen and hydrogen-oxygen gas mixtures. In Proceedings of the Conferenceon Stress-Corrosion Cracking and Hydrogen Embrittlementof Iron-Base Alloys, Firiiny, France, 12-16 June 1973; pp. $382-389$. 
48. Gangloff, R.P.; Wei, R.P. Gaseous hydrogen embrittlement of high strength steels. Metal Mater. Trans. A 1977, 8, $1043-1053$. [CrossRef]

49. Pao, P.; Wei, R. Hydrogen assisted crack growth in 18Ni (300) maraging steel. Scr. Metal 1977, 11, 515-520. [CrossRef]

50. Perng, T.-P.; Altstetter, C.J. Cracking kinetics of two-phase stainless steel alloys in hydrogen gas. Metal Mater. Trans. A 1988, 19, 145-152. [CrossRef]

51. Sawicki, V.R. Hydrogen Induced Cracking in a High Strength Steel. Ph.D. Thesis, Cornell University, Ithaca, NY, USA, 1971.

52. Bergmann, G. Untersuchungen zur Wasserstoffversprödung von NiAl, TiAl und CMSX-6 (in German). In VDI Fortschrittsberichte R. 5, Nr 406; Verein Deutscher Ingenieure: Düsseldorf, Germany, 1995; p. 143.

53. Marchi, C.; Somerday, B.; Robinson, S. Permeability, solubility and diffusivity of hydrogen isotopes in stainless steels at high gas pressures. Int. J. Hydrogen Energy 2007, 32, 100-116. [CrossRef]

54. Jebaraj, J.J.; Morrison, D.J.; Suni, I.I. Hydrogen diffusion coefficients through Inconel 718 in different metallurgical conditions. Corros. Sci. 2014, 80, 517-522. [CrossRef]

55. Marchi, C.S.; Somerday, B.P. Effects of High-Pressure Gaseous Hydrogen on Structural Metals. SAE Trans. 2007, 116, 94-109.

56. Noreña, C.H.; Bruzzoni, P. Effect of microstructure on hydrogen diffusion and trapping in a modified $9 \% \mathrm{Cr}-1 \% \mathrm{Mo}$ steel. Mater. Sci. Eng. A 2010, 527, 410-416. [CrossRef]

57. $\mathrm{Wu}, \mathrm{X}$.; Kim, I. Effects of strain rate and temperature on tensile behavior of hydrogen-charged SA508 Cl.3 pressure vessel steel. Mater. Sci. Eng. A 2003, 348, 309-318. [CrossRef]

58. Vehoff, H. Hydrogen related material problems. In Hydrogen in Metals III; Wipf, H., Ed.; Springer: Berlin/Heidelberg, Germany, 1997; Volume 73, pp. 215-278.

59. Caskey, G.R. Hydrogen damage in stainless steel. In Proceedings of the Conference: International Conference on Environmental Degradation of Engineering Materials, Blacksburg, VA, USA, 21 September 1981; pp. 283-302.

60. Fritzemeier, L.G.; Walter, R.J.; Meisels, A.P.; Jewett, R.P. Hydrogen embrittment research: A Rocketdyne overview. In Proceedings of the 4th International Conference on Effect of Hydrogen on the Behaviour of Materials, Moran, WY, USA, 12-15 September 1989; pp. 941-954.

61. Chandler, W.; Walter, R. Testing to Determine the Effect of High-Pressure Hydrogen Environments on the Mechanical Properties of Metals. In Hydrogen Embrittlement Testing; ASTM International: West Conshohocken, PA, USA, 2009; p. 170.

62. Frandsen, J.D.; Marcus, H.L. Environmentally assisted fatigue crack propagation in steel. Metal Mater. Trans. A 1977, 8, 265-272. [CrossRef]

63. Al-Rumaih, A.M.; Gangloff, R.P. Measurement and Modeling of Temperature Dependent Internal Hydrogen Assisted Cracking in Cr-Mo Steel. In Proceedings of the International Hydrogen Conference (IHC 2012): Hydrogen-Materials Interactions, Jackson Lake Lodge, WY, USA, 9-12 September 2014; pp. 33-48.

64. Al-Rumaih, A.M.; Gangloff, R.P. New fracture mechanice approach to characterize internal hydrogen embrittlement of steel for fitness-for-service modeling. In Proceedings of the 11th International Conference on Fracture, Turin, Italy, 20-25 March 2005; p. 5044.

65. Bowker, P.; Hardie, D. The Tensile Ductility of a High-Strength Steel in an Atmosphere of Hydrogen. Metal Sci. 1975, 9, 432-436. [CrossRef] 